\title{
In vitro Antimicrobial Effectiveness of Selected Medicinal Plants Extract against Pathogenic Organisms
}

\author{
Jana Soma $^{1}$, Yalagatti S. Manjunath ${ }^{2}$ and Gupta V. Rama Mohan ${ }^{3}$ \\ ${ }^{1}$ Department of Pharmaceutical Chemistry, Bharat Technology, Howrah, India \\ ${ }^{2}$ Department of Pharmaceutical Chemistry, Srikrupa Institute of Pharmaceutical Sciences, \\ Siddipet, Telangana, India \\ ${ }^{3}$ Department of Pharmaceutics, Pulla Reddy Institute of Pharmacy, Medak, Hyderabad, India \\ *Corresponding author
}

\begin{tabular}{|c|c|}
\hline & A B S T R A C T \\
\hline & \multirow{8}{*}{$\begin{array}{l}\text { Global prevalence of infectious diseases caused by microorganism is a major public health } \\
\text { problem. Resistance against antibiotics of abundant bacteria is gradually acquiring. } \\
\text { Therefore, investigation for new inventive plant materials with antimicrobial activity has } \\
\text { become an insistent necessity. The present study aimed to investigate the antimicrobial } \\
\text { potential of ethanol and aqueous aerial extracts of Mikania scandens, Croton } \\
\text { bonplandianum Baill and Eupatorium triplinerve against gram positive, gram negative } \\
\text { bacteria and fungus strains by using agar well diffusion assays and their activities were } \\
\text { further determined by Minimum inhibitory concentration (MIC), Minimum bactericidal } \\
\text { concentration (MBC), Minimum fungal concentration (MFC) assays. The selected plants } \\
\text { were found to possess antimicrobial activity against selected pathogenic microorganisms. } \\
\text { Comparative study revealed that the alcoholic extracts of all plants exhibited higher broad } \\
\text { spectrum antimicrobial activity than aqueous extracts. The inhibitory property of the } \\
\text { ethanol extract of } C \text {. bonplandianum (EECB) was observed within range of conc. from } 2 \\
\text { to } 1024 \mu \mathrm{g} / \mathrm{ml} \text {. Ethanol extract of } C \text {. bonplandianum ( EECB) was showed significant } \\
\text { antibacterial activity with MIC of } 128 \mu \mathrm{g} / \mathrm{ml} \text { against both gram (+ve \& -ve) and antifungal } \\
\text { activity with the same MFC value, MBC of } 256 \mu \mathrm{g} / \mathrm{ml} \text { against gram +ve and fungal } \\
\text { strains. The overall results indicates ethanol aerial extracts of C. bonplandianum (EECB) } \\
\text { can serve as most effective potential source of antimicrobial activities than other plants. }\end{array}$} \\
\hline Keywords & \\
\hline $\begin{array}{l}\text { Antimicrobial, } \\
\text { Agueeus and }\end{array}$ & \\
\hline Ethanol extract. & \\
\hline & \\
\hline Article Info & \\
\hline $\begin{array}{l}\text { Accepted: } \\
\text { 17 June } 2018 \\
\text { Available Online: } \\
\text { 10 July } 2018\end{array}$ & \\
\hline & \\
\hline
\end{tabular}

\section{Introduction}

Natural products, either as pure compounds or as standardized plant extracts, contribute enormous opportunities for new drug leads because of the unrivalled accessibility of chemical diversity. Usually wild plants have provided mankind with medicine to alleviate suffering from different infectious diseases since ancient times. They are novel source of medicines as they have assortment of chemical agents with potential therapeutic properties. Different aerial part of plant has been used since ancient time either extracted raw compound or a paste. Although, several plant species have been evaluated as a choice for 
antimicrobial activity, still there is a need for more research in this field. Plants, which are found to possess in-vitro antimicrobial properties, are generally affluent in a variety of phytochemicals including alkaloids, flavonoids, terpenoids, tannins.

M. scandens $C$. bonplandianum, E. triplinerve, have been commonly used for this study. M.scandens, E.triplinerve belonging to the same family Asteraceae. $M$. scandens, herbaceous climbing vine utilised for the treatment of stomach ulcers (Herz et al., 1970; Hasan et al., 2009). In-vitro experiments showed that the $M$. scandens flowers displayed marked anti-inflammatory properties. The leaves are used for analgesic and in vitro antioxidant and antidiabetic activities.

The leaves of exotic plant $C$. bonplandianum (Euphorbiaceae) used for controlling high blood pressure, for the treatment of skin diseases and cuts wounds and also used as antiseptic and antidote. The seeds have the efficacy to cure jaundice, acute constipation, abdominal dropsy and internal abscesses. The leaf extract has been proved to have wound healing effect and external application has shown to cure the ringworm infection. The seed of $C$. bonplandianum contains diterpines, phorbol ester, including 12-orthotrideconeolyphorbol-13-acetate (TPA) and myristoyl phorbol acetate (MPA).

E. triplinerve, perennial plants known as ayapana used for control bleeding from open wounds and blood clotting. The essential oil from the flowers of ayapana was reported to possess antiparasitic and anthelmintic actions. The flower essential oil injected into mice was reported to have CNS depressant, analgesic, and sedative effects.

In the present study, we investigated the potential of three wild Indian plants species for antimicrobial property against the both gram positive and gram negative as well as fungal organisms.

\section{Materials and Methods}

\section{Collection of plant materials and extract preparation}

The aerial parts of Mikania scandens, Croton bonplandianum, Eupatorium triplinerve, were collected from various regions of Midnapore district of West Bengal, India. Collection of plant materials was independent of season. All species were taxonomically established and authenticated by Central National Herbarium, Botanical Garden, Howrah. C. bonplandianum and E. Triplinerve were identified with Reference No. CNH/2017/Tech.II/22 and $M$. scandens was identified with Reference No. CNH/57/2014/Tech.II/278.

After authentification the fresh aerial parts collected in bulk. All plant materials were collected with deionised water, shade dried, and grinded mechanically into coarse powder. The powder plant materials were sequentially extracted with ethanol and water $(1200 \mathrm{ml})$ according to their increasing polarity by using Soxhlet apparatus for $24 \mathrm{~h}$ at a temperature not exceeding the boiling point of the respective solvent.

The obtained extracts were concentrated under vacuum by using rotary evaporator. Both extracts were collected separately and stored in a freezer at $8^{\circ} \mathrm{c}$ temperature until further use.

\section{Phytochemical studies}

Preliminary phytochemical exploration of the both extracts for the presence of different secondary metabolites such as glycosides, alkaloids, flavonoids, saponins, steroids, tannins were carried out. 
Table.1 List of plant species used in the study

\begin{tabular}{|c|c|c|c|c|}
\hline Sl.No. & Species & Family & Vernacular name & Plant materials \\
\hline i) & Mikania scandens & Asteraceae & Climbing hempvine & Screened leaf, stem, flowers, fruits \\
\hline ii) & Croton bonplandianum & Euphorbiaceae & Bantulsi & Screened leaf, stem, flowers, fruits \\
\hline iii) & $\begin{array}{l}\text { Eupatorium triplinervel } \\
\text { Ayapana triplinerve }\end{array}$ & Asteraceae & Ayapana & Screened leaf, stem, flowers \\
\hline
\end{tabular}

\section{Test strains}

Two gram positive bacteria Bacillus sutbilis (MTCC No.441), Staphylococcus aureus (MTCC No. 3160), two gram negative bacteria Escherichia coli (MTCC No.1652),Salmonella typhi (MTCC No. 733) and two fungal strains Candida albicans (MTCC No.227) Asperigillus niger (MTCC No.282) were obtained from Microbiology department which were kept at $4^{\circ} \mathrm{c}$ on agar slant and subculture at $37^{\circ} \mathrm{c}$ for $24 \mathrm{hrs}$ on nutrient agar before any susceptibility test.

\section{Antimicrobial susceptibility}

\section{Culture media}

Nutrient agar was used for bacteria and savoured dextrose broth for fungi. For the agar well diffusion experiments savoured dextrose agar was employed. The Muller Hinton agar (MHA) medium was used for the minimal inhibition Concentration (MIC) and minimum bactericidal concentration (MBC) determination.

\section{Standard drugs used for antimicrobial agents}

Ciprofloxacin and Fluconazole (Micro Lab, India) were used as reference antibiotics against bacteria and fungi correspondingly.

\section{Preparation of inocula}

For the preparation of the inoculate $24 \mathrm{~h}$ culture was emulsified in $3 \mathrm{ml}$ sterile saline following the McFarland turbidity to obtain a concentration of $10^{8}$ cells $/ \mathrm{ml}$. The suspension was standardized by adjusting the optical density to 0.1 at $600 \mathrm{~nm}$ (ELICO, SL-244 spectrophotometer). One hundred micro litres $(100 \mu \mathrm{l})$ of cell suspension with approximately $10^{6}-10^{8}$ bacteria per millilitre was placed in petridishes and dispersed over agar.

Zone of inhibition determination by agar well diffusion assay:

\section{Antibacterial assay}

Antimicrobial activities of the crude extracts were first screened for their zone of inhibition by the agar well-diffusion method. Shortly, crude extracts were prepared concentration of $50 \mathrm{mg} / \mathrm{ml}$ and $100 \mathrm{mg} / \mathrm{ml}$ with dimethyl sulphoxide (DMSO) as solvent. The Mueller Hinton Agar (MHA) medium (Hi Media) was prepared and sterilised at $121^{\circ} \mathrm{C} 15 \mathrm{lb} / \mathrm{sq}$ for $20 \mathrm{~min}$ the autoclave. Thirty millilitres of this sterilised agar medium (MHA) were poured into each $9 \mathrm{~cm}$ sterile petridishes under aseptic conditions and allowed to settle. In the following, a well was made in the plates with the help of a sterile stainless steel-borer (6 $\mathrm{mm}$ diameter) two holes per plates were made into the set agar containing the bacterial culture. Each well $100 \mu 1$ of the plant extracts at the various concentration. For each bacterial strain controls were maintained where pure solvents, instead of extract as negative control. Ethanol and Aqueous extracts $(50 \mathrm{mg} / \mathrm{ml}$ and $100 \mathrm{mg} / \mathrm{ml})$ and reference drug (Ciprofloxacin100 $\mu \mathrm{g} / \mathrm{ml}$ ) were 
allowed to diffuse for $1 \mathrm{~h}$ into the plates and then incubated at $37^{\circ} \mathrm{C}$ for $18 \mathrm{~h}$ in inverted position. The results were recorded by measuring the zone of growth inhibition in $\mathrm{mm}$ surrounding the wells. Each assay was performed in triplicates and repeated twice.

\section{Antifungal activity}

Both the fungal species was cultured in Potato Dextrose broth for $48 \mathrm{~h}$ at $27^{\circ} \mathrm{C}$ and Savoured Dextrose Agar (SDA) was employed for the agar well diffusion experiments. Fungal suspensions was adjusted to $10^{7}$ cells $/ \mathrm{ml}$. The zone of Inhibition was determined after incubation for $48 \mathrm{~h}$ at $27^{\circ} \mathrm{C}$. Specified test drug ethanol and aqueous extracts $(50 \mathrm{mg} / \mathrm{ml})$ and $(100 \mathrm{mg} / \mathrm{ml})$ and standard drug fluconazole $(100 \mu \mathrm{g} / \mathrm{ml})$ were used respectively. All tests were performed in triplicates and repeated twice.

\section{Minimum inhibitory concentration}

The minimum inhibitory concentration (MIC) is defined as the lowest concentration able to inhibit any visible bacterial growth on the culture plates. Sensitivity of the microorganisms of both ethanol and aqueous extracts of selected plants can be measured by using tube dilution method where it can show the bactericidal or bacteriostatic. Each tube contained an inoculums density of $5 \times 10^{5}$ $\mathrm{CFU} / \mathrm{mL}$ of each of the test organisms. All organisms were grown in Muller Hinton broth. Then the suspension of all the four cultures was added into tubes containing diluted sample of $C$. bonplandianum, $E$. triplinerve, $M$. scandens extracts 2-1024 $\mu \mathrm{g} / \mathrm{mL}$. The dilution of the samples was done with Mueller Hinton broth. Finally, the tubes containing diluted sample of and bacteria was then incubated overnight at $37^{\circ} \mathrm{C}$ with constant shaking on the shaker. The growth of the microorganisms was determined by turbidity. Clear tubes indicated absence of bacterial growth. For every experiment, a sterility check (ethanol, medium) negative control (ethanol, medium, inoculums) and different standard antibiotics individually were included. The MIC of the samples was the lowest concentration in the medium that completely inhibited the visible growth. The solvent value was deducted accordingly to get the final results of activity.

\section{Minimum Bactericidal concentration (MBC) and Minimum Fungicidal Concentration (MFC) assessment}

The minimal bactericidal concentration (MBC) was determined by using the method of Vila et al. To determine the $\mathrm{MBC}$ and minimal fungicidal concentration (MFC) of the plant extracts against the microorganisms, the plates of the MIC that showed no growth of the microbes were sub-cultured by striping using wire loop on sterile Muller Hinton agar plates. The plates were incubated at $37^{\circ} \mathrm{C}$ for $18-24 \mathrm{~h}$ and at $25^{\circ} \mathrm{C}$ for $48 \mathrm{~h}$ respectively for bacteria and fungi. The MBC and MFC were taken as the lowest concentration of the extract that exhibited not microbial growth on the agar plates.

\section{Evaluation of bactericidal and bacteriostatic capacity}

The action of an antibacterial on the bacterial strains can be characterized at two parameters as $\mathrm{MIC}$ and $\mathrm{MBC}$. Accordingly to the ratio $\mathrm{MBC} / \mathrm{MIC}$, we can apperceive antibacterial activity. If the ratio $\mathrm{MBC} / \mathrm{MIC}=1$ or 2 , effect is bactericidal but if the ratio $\mathrm{MBC} / \mathrm{MIC}=4$ or 16 , effect is bacteriostatic.

\section{Results and Discussion}

\section{Phytochemical evaluation}

The preliminary phytochemical analysis of ethanol and aqueous extracts of $M$. scandens, 
C. bonplandianum, and E. triplinerve revealed that these plants content flavonoids, alkaloids, tannins, glycosides. Flavonoids were present in both extracts of all selected plants. Alkaloids were present in both extracts of $M$. scandens and aqueous extracts of $C$. bonplandianum and E. Triplinerve. Tannins were present in both extracts of selected plants except ethanol extract of $M$. scandens (Table 2).

\section{Antimicrobial susceptibility}

In this study, in-vitro antimicrobial activity of $M$. scandens, $C$. bonplandianum, and $E$. triplinerve ethanol and aqueous extracts of 2 gram positive, 2 gram negative bacterial strains and 2 fungal strains showed antimicrobial activity (Table 3 ) followed by the agar-well diffusion assay compared with standard antibiotics such as ciprofloxacin and fluconazole which were used as positive controls. The results showed that selected medicinal plant extracts possess antimicrobial activities against all pathogenic microorganisms (B.subtilis, S.aureus, E.coli, S.typhi, C.albicans, A.niger) in dose dependent manner. The highest inhibition activities were observed with the ethanol extract of $C$. bonplandianum on both gram negative bacterial strains E.coli and S.typhi at the dose of $100 \mathrm{mg} / \mathrm{ml}$ than comparatively E.triplinerve and M.scandens. The gram positive strains also showed significant sensitivity of all plants.

The selected plants showed also potent sensitivity antifungal activities against both the fungal strains (Table 3).

The agar well diffusion assay is a qualitative, non standardised method useful only for the screening of large numbers of samples. Activities revealed with well diffusion assay were confirmed using the micro dilution broth method. Accordingly both the methods, the antimicrobial activities could be qualified and quantified by inhibition zone diameter, MIC and minimum bactericidal or fungicidal concentration(MBC/MFC) of the extracts. The MIC and MBC/MFC values were used to compare the antimicrobial activity of extracts. The results of MIC,MBC and MFC values showed in Table 4 and 5. The data indicate that the extracts exhibited variable levels of antimicrobial activity against the invested microorganisms. The inhibitory property of the ethanol and aqueous extracts of selected plants were observed within a range of concentration from 2 to $1024 \mu \mathrm{g} / \mathrm{ml}$. The ethanol extract of M.scandens showed a significant antibacterial activity with MIC of $128 \mu \mathrm{g} / \mathrm{ml}$ S.aureus, S.typhi, MFC of $128 \mu \mathrm{g} / \mathrm{ml}$ obtained for the A.niger and aqueous extract of M.scandens with MIC of $128 \mu \mathrm{g} / \mathrm{ml}$ S.aureus, S.typhi, MFC of 128 $\mu \mathrm{g} / \mathrm{ml}$ found for the C.albicans. The other two plant extracts values were given the same table 4. The bactericidal and bacteriostatic effect was determined using the ratio $\mathrm{MBC} / \mathrm{MIC}$ and MFC/MIC.

Contagious diseases are the primary cause of morbidity and mortality worldwide. The number of multidrug resistant microbial strains and the emergence of strains which alleviate susceptibility to antibiotics are continually increasing. Such effect has been attributed to indiscriminate use of broad spectrum antibiotics, immunosuppressive agents and ongoing epidermis of human immunodeficiency virus (HIV) infections. This condition provided the impetus to the finding for new antimicrobial substances from various source such medicinal plants.

The plants have traditionally provided a source of hope for novel drug compounds, as plant herbal mixtures have made large contributions to human health and well being. The use of plant extracts with known antimicrobial properties can be of great significance for therapeutic treatment. 
Table.2 Phytochemical analysis of selected plant samples

\begin{tabular}{|c|c|c|c|c|c|c|c|}
\hline \multirow[t]{2}{*}{ Sl. No. } & \multirow[t]{2}{*}{ Constituent } & \multicolumn{2}{|c|}{ M.scandens } & \multicolumn{2}{|c|}{ C.bonplandianum } & \multicolumn{2}{|c|}{ E.triplinerve } \\
\hline & & $\begin{array}{l}\text { Ethanol } \\
\text { extract }\end{array}$ & $\begin{array}{l}\text { Aqueous } \\
\text { extract }\end{array}$ & $\begin{array}{l}\text { Ethanol } \\
\text { extract }\end{array}$ & $\begin{array}{l}\text { Aqueous } \\
\text { extract }\end{array}$ & $\begin{array}{l}\text { Ethanol } \\
\text { extract }\end{array}$ & $\begin{array}{l}\text { Aqueous } \\
\text { extract }\end{array}$ \\
\hline 1. & Flavonoids & + & + & + & + & + & + \\
\hline 2. & Alkaloids & + & + & + & + & + & - \\
\hline 3. & Saponin & - & + & - & + & - & + \\
\hline 4. & Tannins & - & + & + & + & + & + \\
\hline 5. & Steroid & + & - & - & - & - & - \\
\hline 6. & Glycosides & + & - & - & - & - & + \\
\hline
\end{tabular}

(+) sign indicates presence and (-) sign indicates absence of phytoconstituent.

Table.3 Results of zone of inhibition (mm) in antimicrobial activities

\begin{tabular}{|c|c|c|c|c|c|c|c|c|c|c|c|c|c|}
\hline \multirow[t]{3}{*}{$\begin{array}{l}\text { Sl } \\
\text { no. }\end{array}$} & \multirow[t]{3}{*}{ Groups } & \multicolumn{4}{|c|}{$\begin{array}{c}\text { Antibacterial activity } \\
\text { (gram+ve) }\end{array}$} & \multicolumn{4}{|c|}{$\begin{array}{c}\text { Antibacterial activity } \\
\text { (gram-ve) }\end{array}$} & \multicolumn{4}{|c|}{ Antifungal activity } \\
\hline & & \multicolumn{2}{|c|}{ B. subtilis } & \multicolumn{2}{|c|}{ S. aureus } & \multicolumn{2}{|c|}{ E. coli } & \multicolumn{2}{|c|}{ S. typhi } & \multicolumn{2}{|c|}{ C. albicans } & \multicolumn{2}{|c|}{ A. niger } \\
\hline & & $\begin{array}{l}50 \\
\mathrm{mg} / \\
\mathrm{ml}\end{array}$ & $\begin{array}{l}100 \\
\mathrm{mg} / \\
\mathrm{ml}\end{array}$ & $\begin{array}{l}50 \\
\mathrm{mg} / \\
\mathrm{ml}\end{array}$ & $\begin{array}{l}100 \\
\mathrm{mg} / \\
\mathrm{ml}\end{array}$ & $\begin{array}{l}50 \\
\mathrm{mg} / \\
\mathrm{ml}\end{array}$ & $\begin{array}{l}100 \\
\mathrm{mg} / \\
\mathrm{ml}\end{array}$ & $\begin{array}{l}50 \\
\mathrm{mg} / \\
\mathrm{ml}\end{array}$ & $\begin{array}{l}100 \\
\mathrm{mg} / \\
\mathrm{ml}\end{array}$ & $\begin{array}{l}50 \\
\mathrm{mg} / \\
\mathrm{ml}\end{array}$ & $\begin{array}{l}100 \\
\mathrm{mg} / \\
\mathrm{ml}\end{array}$ & $\begin{array}{l}50 \\
\mathrm{mg} / \\
\mathrm{ml}\end{array}$ & $\begin{array}{l}100 \\
\mathrm{mg} / \\
\mathrm{ml}\end{array}$ \\
\hline 1 & EEMS & $\begin{array}{l}13.3 \\
\pm \\
0.55\end{array}$ & $\begin{array}{l}18.7 \\
\pm \\
0.18\end{array}$ & $\begin{array}{l}17.5 \\
\pm \\
0.83\end{array}$ & $\begin{array}{l}23.6 \\
\pm \\
0.33\end{array}$ & $\begin{array}{l}19.2 \\
\pm \\
0.81\end{array}$ & $\begin{array}{l}24.5 \\
\pm \\
0.93\end{array}$ & $\begin{array}{l}13.4 \\
\pm \\
0.38\end{array}$ & $\begin{array}{l}16.9 \\
\pm \\
0.43\end{array}$ & $\begin{array}{l}23.7 \\
\pm \\
0.53\end{array}$ & $\begin{array}{l}25.6 \\
\pm \\
0.81\end{array}$ & $\begin{array}{l}19.5 \\
\pm \\
0.39\end{array}$ & $\begin{array}{l}24.9 \\
\pm \\
0.33\end{array}$ \\
\hline 2 & AEMS & $\begin{array}{l}10.3 \\
\pm \\
0.54\end{array}$ & $\begin{array}{l}14.9 \\
\pm \\
0.32\end{array}$ & $\begin{array}{l}13.4 \\
\pm \\
0.93\end{array}$ & $\begin{array}{l}16.6 \\
\pm \\
0.81\end{array}$ & $\begin{array}{l}12.5 \\
\pm \\
0.83\end{array}$ & $\begin{array}{l}16.9 \\
\pm \\
0.13\end{array}$ & $\begin{array}{l}10.9 \\
\pm \\
0.39\end{array}$ & $\begin{array}{l}14.5 \\
\pm \\
0.73\end{array}$ & $\begin{array}{l}17.5 \\
\pm \\
0.23\end{array}$ & $\begin{array}{l}21.4 \\
\pm \\
0.63\end{array}$ & $\begin{array}{l}16.8 \\
\pm \\
0.23\end{array}$ & $\begin{array}{l}21.5 \\
\pm \\
0.53\end{array}$ \\
\hline 3 & EECB & $\begin{array}{l}19.3 \\
\pm \\
0.81\end{array}$ & $\begin{array}{l}22.8 \\
\pm \\
1.24\end{array}$ & $\begin{array}{l}18.3 \\
\pm \\
0.81\end{array}$ & $\begin{array}{l}24.4 \\
\pm \\
1.24\end{array}$ & $\begin{array}{l}19.6 \\
\pm \\
0.47\end{array}$ & $\begin{array}{l}25.3 \\
\pm \\
1.63\end{array}$ & $\begin{array}{l}16.6 \\
\pm \\
0.47\end{array}$ & $\begin{array}{l}23.3 \\
\pm \\
1.24\end{array}$ & $\begin{array}{l}25.3 \\
\pm \\
0.31\end{array}$ & $\begin{array}{l}28.1 \\
\pm \\
0.18\end{array}$ & $\begin{array}{l}19.9 \\
\pm \\
0.38\end{array}$ & $\begin{array}{l}24.3 \\
\pm \\
0.22\end{array}$ \\
\hline 4 & AECB & $\begin{array}{l}16.6 \\
\pm \\
1.94\end{array}$ & $\begin{array}{l}18.2 \\
\pm \\
1.69\end{array}$ & $\begin{array}{l}14.6 \\
\pm \\
1.49\end{array}$ & $\begin{array}{l}18.6 \\
\pm \\
1.09\end{array}$ & $\begin{array}{l}13.3 \\
\pm \\
1.24\end{array}$ & $\begin{array}{l}21.3 \\
\pm \\
0.94\end{array}$ & $\begin{array}{l}14.6 \\
\pm \\
1.24\end{array}$ & $\begin{array}{l}22.7 \\
\pm \\
1.16\end{array}$ & $\begin{array}{l}17.3 \\
\pm \\
0.31\end{array}$ & $\begin{array}{l}21.5 \\
\pm \\
0.23\end{array}$ & $\begin{array}{l}16.2 \\
\pm \\
0.21\end{array}$ & $\begin{array}{l}18.5 \\
\pm \\
0.39\end{array}$ \\
\hline 5 & EEET & $\begin{array}{l}18.3 \\
\pm \\
1.94\end{array}$ & $\begin{array}{l}22.7 \\
\pm \\
1.24\end{array}$ & $\begin{array}{l}19.6 \\
\pm \\
1.63\end{array}$ & $\begin{array}{l}23.3 \\
\pm \\
1.62\end{array}$ & $\begin{array}{l}21.6 \\
\pm \\
1.24\end{array}$ & $\begin{array}{l}23.8 \\
\pm \\
2.18\end{array}$ & $\begin{array}{l}22.3 \\
\pm \\
2.05\end{array}$ & $\begin{array}{l}25.0 \\
\pm \\
1.63\end{array}$ & $\begin{array}{l}23.2 \\
\pm \\
0.61\end{array}$ & $\begin{array}{l}24.8 \\
\pm \\
0.13\end{array}$ & $\begin{array}{l}20.8 \\
\pm \\
0.31\end{array}$ & $\begin{array}{l}24.0 \\
\pm \\
0.32\end{array}$ \\
\hline 6 & AEET & $\begin{array}{l}15.7 \\
\pm \\
2.16\end{array}$ & $\begin{array}{l}20.6 \\
\pm \\
1.24\end{array}$ & $\begin{array}{l}16.1 \\
\pm \\
2.05\end{array}$ & $\begin{array}{l}19.4 \\
\pm \\
2.16\end{array}$ & $\begin{array}{l}17.6 \\
\pm \\
2.86\end{array}$ & $\begin{array}{l}18.3 \\
\pm \\
0.47\end{array}$ & $\begin{array}{l}17.6 \\
\pm \\
2.05\end{array}$ & $\begin{array}{l}21.3 \\
\pm \\
2.5\end{array}$ & $\begin{array}{l}18.0 \\
\pm \\
0.31\end{array}$ & $\begin{array}{l}24.5 \\
\pm \\
0.23\end{array}$ & $\begin{array}{l}15.0 \\
\pm \\
0.21\end{array}$ & $\begin{array}{l}22.0 \\
\pm \\
0.31\end{array}$ \\
\hline 7 & $\mathrm{CPF}$ & \multicolumn{2}{|c|}{$23.9 \pm 0.51$} & \multicolumn{2}{|c|}{$25.6 \pm 0.25$} & \multicolumn{2}{|c|}{$27.2 \pm 0.62$} & \multicolumn{2}{|c|}{$28.4 \pm 0.56$} & & & \multicolumn{2}{|c|}{$x^{2}$} \\
\hline 8 & FLZ & & & & & & & & & $32 \pm 0$ & & $29.3 \pm$ & \\
\hline 9 & CNT & - & & - & & - & & - & & - & & & \\
\hline
\end{tabular}

EEMS-Ethanol extract of $M$. scandens, AEMS-Aqueous extract of M.scandens, EECB-Ethanol extract of C.bonplandianus, AECB-Aqueous extract of C.bonplandianum, EEET-ethanol extract of E.triplinerve, AEATAqueous extract of E.triplinerve, CPF-Ciprofloxacin $(100 \mu \mathrm{g} / \mathrm{ml})$, FLZ-Fluconazole (100 $\mu \mathrm{g} / \mathrm{ml})$, CNT-Control 
Table.4 MIC, MBC and MFC determination, bactericidal (+) and bactriostatic (-) effect of the ethanol extracts of selected plants

\begin{tabular}{|l|l|l|l|l|l|l|l|l|l|l|l|l|l|l|}
\hline $\begin{array}{l}\text { Sl. } \\
\text { No }\end{array}$ & M.O & \multicolumn{3}{|l|}{ M.scandens } & \multicolumn{3}{l|}{ C.bonplandianus } & \multicolumn{3}{l|}{ E.triplinerve } \\
\hline & & MIC & $\begin{array}{l}\text { MBC } \\
\text { or } \\
\text { MFC }\end{array}$ & $\begin{array}{l}\text { MBC } \\
\text { /MIC }\end{array}$ & Effect & MIC & $\begin{array}{l}\text { MBC } \\
\text { or } \\
\text { MFC }\end{array}$ & $\begin{array}{l}\text { MBC } \\
\text { /MIC }\end{array}$ & Effect & MIC & $\begin{array}{l}\text { MBC } \\
\text { or } \\
\text { MFC }\end{array}$ & $\begin{array}{l}\text { MBC } \\
\text { /MIC }\end{array}$ & Effect \\
\hline $\mathbf{1}$ & SA & 128 & 512 & 4 & - & 128 & 256 & 2 & + & 256 & 512 & $>4$ & Nd \\
\hline $\mathbf{2}$ & BS & 1024 & NA & NA & - & 128 & 256 & 2 & + & 1024 & NA & - & - \\
\hline $\mathbf{3}$ & EC & 256 & 512 & 2 & + & 128 & 512 & 4 & - & 256 & 1024 & 4 & - \\
\hline $\mathbf{4}$ & ST & 128 & 512 & 4 & - & 256 & 512 & 2 & + & 128 & 512 & 4 & - \\
\hline $\mathbf{5}$ & CA & 256 & 512 & 2 & + & 128 & 256 & 2 & + & 128 & 512 & 4 & - \\
\hline $\mathbf{6}$ & AN & 128 & 1024 & 4 & - & 256 & 512 & 2 & + & 256 & 1024 & 4 & - \\
\hline
\end{tabular}

SA- Staphylococcus aureus, BS - Bacillus sutbilis, EC - Escherichia coli, ST- Salmonella typhi, CA - Candida albicans, AN - Asperigillus niger,NA-No Activity, Nd-No detected activity

Table.5 MIC, MBC and MFC determination, bactericidal (+) and bactriostatic (-) effect of the aqueous extracts of selected plants

\begin{tabular}{|l|l|l|l|l|l|l|l|l|l|l|l|l|l|}
\hline S1.No & M.O & \multicolumn{4}{l}{ M.scandens } & \multicolumn{4}{l|}{ C.bonplandianus } & \multicolumn{3}{l|}{ E.triplinerve } \\
\hline & & MIC & MBC & $\begin{array}{l}\text { MBC/ } \\
\text { MIC }\end{array}$ & Effect & MIC & MBC & $\begin{array}{l}\text { MBC/ } \\
\text { MIC }\end{array}$ & Effect & MIC & MBC & $\begin{array}{l}\text { MBC/ } \\
\text { MIC }\end{array}$ & Effect \\
\hline $\mathbf{1}$ & SA & 128 & 256 & 2 & + & 128 & 256 & 2 & + & 128 & 512 & 4 & - \\
\hline $\mathbf{2}$ & BS & 256 & 1024 & 4 & - & 128 & 512 & 4 & - & 256 & 1024 & 4 & - \\
\hline $\mathbf{3}$ & EC & 512 & 1024 & 2 & + & 128 & 512 & 4 & - & 1024 & NA & - & - \\
\hline $\mathbf{4}$ & ST & 128 & 512 & 4 & - & 256 & 512 & 2 & + & 128 & 512 & 4 & - \\
\hline $\mathbf{5}$ & CA & 128 & 512 & $<2$ & - & 256 & 1024 & 4 & - & 512 & 1024 & 2 & + \\
\hline $\mathbf{6}$ & AN & 256 & NA & NA & - & 512 & 1024 & 2 & + & 512 & 1024 & 2 & + \\
\hline
\end{tabular}

In the present study, ethanol and aqueous extract of $M$. scandens, $C$. bonplandianum, $E$. Triplinerve exhibited dose dependent activity against all the tested pathogenic microbial strains with inhibition activity varied from one plant to another. But comparatively alcoholic extracts of all plants exhibits higher antimicrobial activity due to nature of biological active components which may be enhanced in the presence of ethanol than the aqueous extract. This is due to high polarity of alcoholic solvents which naturally has ability to extracting high quantity of phytochemicals. Among 3 plants extracts $C$. bonplandianum aerial parts extract exhibited maximum zone of inhibition both gram positive as well as gram negative bacteria and also the fungal species. $M$. scandens, $E$. Triplinerve aerial parts extract showed significant activity.

The antimicrobial activity could be due to the presence of single bioactive compound or combined action of many compounds contained in the extract. Plant components with phenolic structures are highly active against the microorganisms. Several studies have shown that various phytochemicals compound like flavonoids, alkaloids, tannins, saponins, reducing sugar, steroids, glycoside are present in $M$. scandens, $C$. bonplandianum, E. Triplinerve. Polyphenols like flavonoids and tannins (Cowan, 1999) are 
important of antimicrobial activity. The highest antimicrobial activity of ethanol extract of C.bonplandianum may be attributed to the presence of active ingredients of flavonoids like quercetin and rutin (Sumahy Arokiasamy and Narendra kumar Singh et $a l .$,$) . The stronger antimicrobial activity of$ flavonoids is due to their ability to complex with extracellular and soluble protein and to complex with bacterial cell wall synthesis in the effected organisms while that of tannins may be related to their ability to inactivate microbial adhesion, enzymes and cell envelop proteins. The bacteriostatic and bacteriocidal activity could be ascribed to the presence of polyphenol compounds.

In conclusion, this study revealed the efficacy of $C$. bonplandianum, $M$. scandens, $E$. Triplinerve as antimicrobial agents against all the tested pathogenic microorganisms. Comparative antimicrobial evaluation among the plants under examination showed that $C$. bonplandianum ethanol extracts can serve as most effective antimicrobial agents than other two plants. Further research is required for isolation and identification of active principles present in the extract for showing the infectious ailments.

\section{Acknowledgement}

The authors are thankful to Prof.(Dr.) D. Karthikeyan. Principal, Srikrupa Institute of Pharmaceutical Sciences, Siddipet, Telengana, Indiafor availing the laboratory facilities during the course of research studies.

\section{References}

Akinyele, T.A., Okoh, O. O, Akinppelu, D.A., Okoh, Al., 2011. In -Vitro antibacterial properties of crude aqueous and n-hexane extracts of the husk of Cocos nucifera. Mol. 16(3):2135-45.

Akinyemi KO, Oladapo O, Okwara CE, Ibe CC, Fasure KA. 2005. Screening of crude extracts of six medicinal plants used in South West Nigerian unorthodox medicine for anti-methicillin resistant staphylococcus aureus activity. 2005.BMC complement Altern. Med:5-6.

A.M. Sandigawad.2010. In vitro evaluation of antibacterial activity of bark and flower extracts of pimenta officinalis Lindi, Adv. Biores.1(2): 61-68.

Bhakat RK., Sen UK. 2008. Ethnomedicinal plant conservation through sacred groves. Tribes and Tribals.2: 55-58.

Chandra S., Dey P., Bhattacharya S et al., 2012. Preliminary in vitro assessment of antiinflammatory property of Mikania scandens flower extract. Journal of Advanced Pharmacy Education \& Research, 2(1):25-31.

Cowan MM. 1999. Plants products as antimicrobial agents, Clin Microbiol Rev 12: 564-582.

Divya S., Naveen Krishna K., Ramachandran S and Dhanaraju M.D.2011. Wound Healing and In Vitro Antioxidant Activities of Croton bonplandianum Leaf Extract in Rats. Global Journal of Pharmacology 5 (3): 159-163.

Dorman HJ., Deans SG. 2000. Antimicrobial agents from plants, antibacterial activity of plant volatile oils. J Appl Microbiol 88: 308-316.

Garg S. C. 1993 "Studies on the essential oil from the flowers of Eupatorium triplinerve." Indian Perfume 37 (4): 318-323.

Hasan, SMR., Mariam, Jamila., Majumder, M.M., Raushanara, Akter., Hossain, M.M., Mazumder, MEH., Alam, MA., Rumana, Jahangir., Rana, M.S., Arif. M, Rahman. S., 2009. Analgesic and antioxidant activity of the hydromethanolic extract of Mikania scandens (L.) Willd. leaves. American Journal of Pharmacology and Toxicology. 4(1): 1-7.

Hoffman D.L. 1987.The herb user's guide. London, Thomsonious publishing group.

I.Wu.M.W., A.R. Duncan and C.O. Okunji. 1999. J. ASHA Press Alexandra V.A. pp. 457 462.

J.B. Harborne., Phytochemical Methods A Guide to Modern Technique of Plant Analysis, Chapman and Hall Ltd., London 49-188. 
Kokate C. K. et al., "Pharmacological studies on the essential oil of Eupatorium triplinerve effects on the central nervous system Flavour. 1971; 2 (3): 177-180.

Kumarasamy, Y., Cox. P.J., Jaspars, M, Nahar L, Sarker SD 200.2 Screening seeds of Scottish plants for antibacterial activity. J Ethnopharmacol 83: 73-77.

Malini, M., Abirami, G., Hemalatha,V., Annadurai, G. 2013. Antimicrobial activity of ethanolic and aqueous extracts of medicinal plants against waste water pathogens. Inter $\mathbf{J}$ Res Pure Appl Microbiol 3: 40-42.

Medini, F., Fellah, H., Ksouri, R., Abdelly, C 2014. Total phenolic, flavonoids and tannin contents and antioxidant and antimicrobial activities of organic extracts of shoots of the plant Lomonium delicatulum. Journal of Taibah University for Science 8 (3): 216-224.

Nasa,r Abbas SM., Halkman AK. 2004. Antimicrobial effect of water extract of sumac (Rhus coriaria L.) on the growth of some food borne bacteria including pathogens. Int J Food Microbiol 97:63-69.

Olurinola P.F.1996. A laboratory manual of pharmaceutical microbiology, Idu, Abjua, Nigeria, National Institute for pharmaceutical Research and Development. p.69-105.

P Tiwari., B. Kumr., M. Kaur, et al., 2011. Phytochemical screening and extraction, a review, Int.Pharm.Sci. 98-106.

Reddy K.R. 1995. Folk medicines from Chittor District Andra Pradesh, used in treatment of jaundice. Pharm Biol, 26: 137-140.

Samy R.P. Ignacimuthu, S., 2000. Antibacterial activity of some folklore medicinal plants used by tribals in Western Ghats in India. J Ethnopharmacol 69: 63-71.

Spencer ALR, Spencer JFT. 2004 Public Health Microbiology: Methods and protocols. New Jersey; Human Press Inc;.p.325-7.

Sunayana, V., Vadivukkarasi A, Rajendran T, Franchis X, Natarajan E 2003. Antibacterial potential of Plectranthus amboinicus (Lour) Spreng. A study in vitro J Swamy Bot club 20:55-8.

Talib WH, Mahasneh AM. 2010. Antimicrobial, cytotoxicity and phytochemical screening of Jordanian plants used in traditional medicine. Molecules 15, 1811-1824.

Trease, G.E., Evans,W.C. 2002. Pharmacognosy, $15^{\text {th }}$ ed. Springer, Berlin.

Uniyal SK., Singh KN., Jamwal P., Lal B 2006. Traditional use of medicinal plants among the tribal communities of Chhota Bhangal, Western Himalayan. J. Ethnobiol Ethnomed.

Vila R. Santana, A. PeezRoses, R. Valderrama, A. Castelli, M.V, Mendonca, S. Zacchino, S. Gupta, M.P., Salvador, B.A. Composition and biological activity of the essential oil from leaves of Plinia cerrocamanensis, a new source of $\alpha$-bisabolol. Bioresour. Technol. 101, 2510-2514.

Zhang R., Eggleston K., Rotimi V., Zeckhauser RJ 2006. Antibiotic resistance as a global threat: evidence from China, Kuwait and the United States. Global Health 2-6.

\section{How to cite this article:}

Jana Soma, Yalagatti S. Manjunath and Gupta V. Rama Mohan 2018. In vitro Antimicrobial Effectiveness of Selected Medicinal Plants Extract Against Pathogenic Organisms.. Int.J.Curr.Microbiol.App.Sci. 7(07): 2211-2219. doi: https://doi.org/10.20546/ijcmas.2018.707.259 